Ann. Biol. anim. Bioch. Biophys., I976, 16 (2), 253-263.

\title{
LH-RH THERAPY OF HUMAN INFERTILITY
}

\author{
Jacqueline MANDELBAUM, D. MILLET and A. NETTER \\ Service d'Endocrinologie et de Gynécologie, \\ Hôpital Necker, \\ 75730 Paris Cedex 15
}

\section{SUMMARY}

Before considering the various therapeutic techniques and their results, the authors recall some of the biological properties and the efficiency of the various routes of administration of synthetic LH-RH,

In the female, functional anovulatory sterility seems to be the disorder eligible for this kind of therapy. Several patterns of treatment have been used : some using LH-RH alone, the others using an association with HMG, clomifene citrate, or HCG. However, the results are, for the moment, rather deceiving in terms of percentage of ovulation and pregnancies. The authors are thinking that the majority of failures could be related to somewhat anarchic schedules of treatment.

The therapeutic trials with LH-RH in male sterility have been very few. Some success have been obtained in a few cases but they do not exclude chance.

The improvement of results should come from a better understanding of the mechanism involved in the respective release of FSH and LH and from the discovery of a longer lasting LH-RH like substance.

Therapy through hypothalamic extracts was first attempted by IGARASHI $e t$ al. (I968). They used a partially purified bovine median eminence extract which had mainly a FSH like activity. It was administered through the intravenous route, either by injection or by infusion. The oestrogenic effect was measured and chosen as an end-point of its activity. Then HCG or $\mathrm{LH}-\mathrm{RH}$ like median eminence extract was injected in order to trigger ovulation; ovulation was obtained in only 3 out of I4 amenorrheic patients, although most of them had displayed symptoms of oestrogenic stimulation. One patient became pregnant. In a woman pretreated with HMG KASTIN et al. (I97I) induced ovulation and pregnancy through a porcine hypothalamic extract repeatedly injected intramuscularly and then through intravenous infusion.

The isolation and synthesis of LH-RH in the laboratories of SCHALLY (I97I) and of GuILLEMin (I97I) allowed this substance to be widely and wordly used to try and treat anovulation and male sterility. 
Frankly speaking, the results are rather disappointing, in view of the efforts displayed in that direction.

Before considering the various therapeutic techniques and their results, it seems worthwhile to recall some of the biological properties of synthetic LH-RH. (I975).

The half life of LH-RH is 2.7 to 2.9 minutes VIRKUNEN et al. (I974), KELCH

According to VIRKUNEN (I974), to JEFFCOATE and to other groups who find in the urine only a very small percentage of the injected dose, the exogenous $\mathrm{L}_{\mathbf{H}} \mathrm{H}-\mathrm{RH}$, although stable in the plasma, is very rapidly metabolized.

By the intravenous route, $\mathrm{LH}-\mathrm{RH}$ invokes a pituitary release of $\mathrm{LH}$, and, at a lesser degree, of FSH, with a peak $30 \mathrm{~min}$. after the injection and a return to its previous level after 240 min. (fig. I).

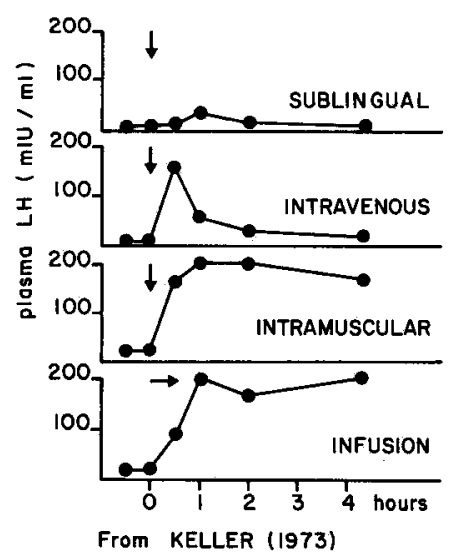

FIG. I. - LH response to $L H-R H$ accoraing to administration route

By the intramuscular route, the stimulation would be longer ( $480 \mathrm{~m}$ ) for RANNEVIK (I973) and KELLER (I972) (fig. I).

By intravenous infusion of $0.2 \mathrm{mcg} / \mathrm{min}$. BREMMER (1974) observes a biphasic response of $\mathrm{LH}$, in contrast to the progressive response of $\mathrm{FSH}$. Then both releases can last as long as the stimulus is maintained.

The subcutaneous route does not seem to have any advantage when compared to the intravenous or intramuscular administration. According to KELLER, the sublingual route is unefficient; on the contrary, the intranasal route could be of interest (SCHNEIDER, I974).

There is a dose-response relationship ; but the major factor of activity seems to be the duration of the administration, owing to the very short life of $\mathrm{L} / \mathrm{H}-\mathrm{RH}$.

So the target response is enhanced by repeating the injections or the inhalations at short intervales or by using constant infusion SCHNEIDER (I974), ZANARTU (I974).

Spacing the injections, on the contrary, deprives the substances of any activity on the peripheral target organs (ZARATE, I972). 


\section{I. - THERAPEUTIC USE IN THE FEMALE}

Needless to mention, the hypophysis should be intact and responsive to a preliminary trial. Functionnal anovulatory sterility seems to be the desorder eligible for this kind of therapy.

Let us first recall that the induction of ovulation and the development of a normal corpus luteum needs three sequential phenomena :

a) follicular maturation, under the action of both FSH and, at a lesser, but necessary degree, LH ;

b) ovulation, due to a potent release of $\mathrm{LH}$ during 36 to 48 hours ;

c) maintenance of the corpus luteus which, in the human species, seems to be related to the maintenance of a supraliminar secretion of $\mathrm{LH}$.

According to this sequence, several patterns of treatment can be suggested, some using LH-RH alone, the others using an association with HMG, clomifene citrate, or HCG.

$$
\text { I. - LR-RH alone (table I) }
$$

Daily intramuscular or subcutaneous doses of 25 to $500 \mathrm{mcg}$ administered once a day or in divided doses, have been used. They are repeated until symptoms of follicular maturation appear : cervical mucus grade 3, superficial vaginal cells,

TABLEAU I

Treatment of anovulatory women with LH-RH

\begin{tabular}{|c|c|c|c|c|c|}
\hline Authors & $\begin{array}{c}\text { Mode of } \\
\text { administration }\end{array}$ & $\mathrm{LH}-\mathrm{RH}$ in $\mathrm{mg}$ & $\begin{array}{l}\text { Number } \\
\text { of cases }\end{array}$ & $\begin{array}{l}\text { Number } \\
\text { of ovulation }\end{array}$ & Pregnancies \\
\hline Abate (1974) & $\mathrm{IM} ; \mathrm{SC} ; \mathrm{P}$ & 0.1 to 1 & & & $36 \%$ \\
\hline AKANDE (1972) & IV; IM ; SC ; P & & 8 & 1 & 0 \\
\hline BRECKWOLDT (1974) & $\mathrm{IM}+$ & 4 & 3 & 0 & 0 \\
\hline Crosignani (1974) & $\mathrm{IM}+$ & & 16 & 0 & 0 \\
\hline Kastin (1974) & $P$ and IV & 1.2 & 1 & 1 & 1 \\
\hline KeLIER (1973) & $\mathbf{I M}+\mathbf{P}$ & 0.05 to 0.5 & 10 & 2 & 0 \\
\hline NAKANO (1974) & IV and SC & 0.4 & 8 & 1 & 1 \\
\hline SCHNEIDER (1974) & $\mathrm{IM}+$ & 1 to 6 & & & $30 \%$ \\
\hline ZANARTU $(1974)$ & $\mathbf{I M}+\mathbf{P}$ & 0.5 to 2.4 & 28 & 13 & 3 \\
\hline ZaRATE $(1972)$ & $\mathrm{IM}+\mathrm{P}$ & 0.2 to 0.5 & 13 & 6 & 2 \\
\hline
\end{tabular}

$\mathrm{P}=$ infusion. 
satisfactory levels of estrogens in blood or urine. This requires 5 to 20 days. Ovulation is then triggered by one or several intramuscular injections or by infusion, during 4 to 6 hours, of Ioo to $500 \mathrm{mcg}$ of LH-RH.

The results are inconsistent : BRECKWOLDT et al. (I974) failed to obtain any estrogenic response in 3 patients with Ioo to $200 \mathrm{mcg}$ per day, divided in two subcutaneous doses.

Crosignani et al. (I974) with a comparable treatment evoked a response in LH and estradiol, but no ovulation.

SCHNEIDER et al. (I974), ABATE et al. (I974) claim an ovulation rate of $30 \mathrm{p}$. Ioo. The nasal route, at the daily rhythm of 3 to 6 snuffs would be the best one, with a rate of ovulation ranging from 50 to $70 \mathrm{p}$. Ioo.

With 28 cycles of treatment through 500 mcg daily, ZANAR'TU obtained I 3 ovulations and 3 patients became pregnant: small doses every 8 to $\mathrm{I} 2$ hours are more active than greater doses administered one daily.

So many authors, so many results! The cases, the patients, the doses used, the intervals between the doses account for this diversity. Unfortunatily, details on the cases are rarely available, information is too poor to draw definite conclusions from the literature.

\section{2. - Treatment with $L H-R H$ followed by $H C G$ (table 2)}

According to ZARATE's schedule $500 \mathrm{mcg}$ intramuscular $\mathrm{LH}-\mathrm{RH}$ are injected in one or two divided doses per day, until the rate of urinary estrogens reaches Ioo micg. Then, ovulation is induced by ro 000 to 20000 units of HCG. With this protocol, ZARATE's results were :

- no ovulation in 6 cases of amenorrhea galactorrhea;

- 4 ovulations in 12 functional amenorrheae with 2 pregnancies;

- 6 ovulations in 24 cases of Stein Leventhal syndrome, with 5 pregnancies. ABate obtains 60 p. Ioo ovulations with this protocol :

With a similar schedule, but using only Ioo mcg per day, CoRTEs et al. (1974) have been unable to induce any ovulation in 5 amenorrheic women.

TABLEAU 2

Treatment of anovulatory women with $L H-R H+H C G$

\begin{tabular}{|c|c|c|c|c|c|}
\hline Authors & $\begin{array}{c}\text { Mode of } \\
\text { administration }\end{array}$ & $\mathrm{LH}-\mathrm{RH}$ in $\mathrm{mg}$ & $\begin{array}{l}\text { Number } \\
\text { of cases }\end{array}$ & $\begin{array}{c}\text { Number } \\
\text { of ovulation }\end{array}$ & Pregnancies \\
\hline ABAte (1974) & $\mathrm{IM} ; \mathrm{SC} ; \mathrm{P}$ & 0.1 to 1 & & $60 \%$ & \\
\hline CoRTES (1974) & $\mathrm{IM}+$ & 2 & 5 & 0 & 0 \\
\hline \multirow{2}{*}{ ZARATE (1974) } & $\mathrm{IM}+$ & 2.5 to 10 & 32 & 9 & 6 \\
\hline & $\mathrm{IM}+$ & 0.8 to 1.6 & 10 & 1 & 1 \\
\hline
\end{tabular}




\section{3. - LH-RH following clomifene citrate (table 3)}

KELLER (I973) used this type of schedule in patients who did not respond to clomifene alone. $2 \mathrm{I}$ patients received roo $\mathrm{mcg}$ clomifene citrate for day during 5 days : 5 to 8 days later, 500 mcg of LH-RH were infused during 4 hours. I 2 ovulations, 2 pregnancies were obtained.

\section{TABLEAU 3}

Treatment of anovulatory women with chlomifene $+L H-R H$

\begin{tabular}{|c|c|c|c|c|}
\hline Authors & $\mathrm{LH} \cdot \mathrm{RH}$ in $\mathrm{mg}$ & $\begin{array}{l}\text { Number } \\
\text { of cases }\end{array}$ & $\begin{array}{c}\text { Number } \\
\text { of ovulation }\end{array}$ & Pregnancies \\
\hline KeLLer (1973) & 0.2 to $0.6\left\{\begin{array}{l}\text { perfusion } \\
\mathrm{IM}\end{array}\right.$ & 21 & 12 & 2 \\
\hline NaKano (1974) & 0.4 & 18 & 9 & 1 \\
\hline
\end{tabular}

\section{4. - LH-RH following $H M G$}

HMG has been used now for more than ten years in order to obtain the follicular ripening which is the necessary step before ovulation can be triggered.

\section{TABLEAU 4}

Treatment of anovulatory women with $H M G+L H-R H$

\begin{tabular}{|c|c|c|c|c|}
\hline Authors & LH-RH/mg & $\begin{array}{l}\text { Number } \\
\text { of cases }\end{array}$ & $\begin{array}{c}\text { Number } \\
\text { of ovulation }\end{array}$ & Pregnancies \\
\hline BRECKWOLDT (1974) & 0.1 to 0.4 perfusion & 8 & 4 & $1 \mathrm{FCS}$ \\
\hline CORTES (1974) & $1.5\left\{\begin{array}{l}\text { perfusion } \\
\text { IM }\end{array}\right.$ & 6 & 4 & 1 \\
\hline Crosignani (1974) & 0.8 to $3 \mathrm{IM}$ & 16 & 5 & $\mathbf{0}$ \\
\hline KeLler (1973) & 0.2 to $0.6\left\{\begin{array}{l}\text { perfusion } \\
\mathrm{IM}\end{array}\right.$ & 8 & 4 & 1 \\
\hline Netter (1974) & 0.1 to $0.7\left\{\begin{array}{l}\text { perfusion } \\
\text { IM }\end{array}\right.$ & $\begin{array}{l}4 \\
4\end{array}$ & $\begin{array}{l}0 \\
1\end{array}$ & $\begin{array}{l}0 \\
0\end{array}$ \\
\hline
\end{tabular}

HCG was used, up to now, for the latter purpose. Some authors have tried to induce ovulation through L,H-RH, instead of HCG. Their techniques and their results are shown in table 4 . 
Our own experience is summarized in table 5 .

As it can be seen, our results are rather disappointing. We have an extensive experience (based upon $\mathbf{I}_{50}$ cases) of the treatment of sterility in amenorrheic women. We may say that presently, with our usual technique, HMG followed by $\mathrm{HCG}$, we obtain ovulation in $90 \mathrm{p}$. Ioo of our cases, and pregnancy in $50 \mathrm{p}$. IOO of them. With HMG followed by LH-RH (see table above) follicular maturation was evoked as usual through HMG. We checked on the other hand, by means of a preliminary test with Ioo mcg of intravenous $\mathrm{L}, \mathrm{H}-\mathrm{RH}$ that our patients were responsive to $\mathrm{LH}-\mathrm{RH}$. However in 4 patients the intravenous infusion of 100 mcg of $\mathrm{LH}-\mathrm{RH}$ during 8 hours was unable to trigger ovulation the day after the last preparing injection of HMG.

\section{TABLE 5}

Attempts to induce ovulation by infusion of LH-RH/100 $\mu \mathrm{g}$ in $8 \mathrm{hrs}$ in four amenorrheic women pretreated by $H M G$

\begin{tabular}{|c|c|c|c|c|c|c|c|}
\hline \multirow{3}{*}{ Etiology } & \multirow{3}{*}{$\begin{array}{c}\mathrm{HMG} \\
\text { (IU) }\end{array}$} & \multirow{3}{*}{$\begin{array}{c}\mathrm{E}_{1}+\mathrm{E}_{2} \\
(\mathrm{pg} / \mathrm{ml}) \\
\text { after } \mathrm{HMG}\end{array}$} & \multicolumn{4}{|c|}{ Response to LH-RH } & \multirow{3}{*}{$\begin{array}{c}\text { Number } \\
\text { of } \\
\text { ovulation }\end{array}$} \\
\hline & & & \multirow[b]{2}{*}{$\begin{array}{c}\text { FSH } \\
(\%)\end{array}$} & \multirow[b]{2}{*}{$\begin{array}{l}\text { LH } \\
(\%)\end{array}$} & \multicolumn{2}{|c|}{ Progesterone (ng/ml) } & \\
\hline & & & & & before & $\begin{array}{l}24 \mathrm{hrs} \\
\text { later }\end{array}$ & \\
\hline Amen-Galac & 2335 & 230 & +150 & +580 & 0.17 & 1.00 & 0 \\
\hline De Morsier & 2925 & 560 & +13 & +84 & 0.28 & 1.14 & 0 \\
\hline Stein Leventhal & 825 & 705 & +462 & +470 & 0.53 & 2.19 & 0 \\
\hline Hyperandrogenie & 675 & 180 & +80 & +510 & 0.38 & 1.03 & 0 \\
\hline
\end{tabular}

Four other patients, instead of receiving infusion, had $200 \mathrm{mcg}$ intramuscularly every twelve hours. The total dose varied from 600 to $700 \mathrm{mcg}$. One patient ovulated, which was proved by the rise of the basal temperature and of the rate of the plasma progesterone. The corpus luteum lasted I9 days. No pregnancy occurred. In another patient, the temperature rose, but the plasma progesterone remained low until we injected HCG, which evoked and maintained the corpus luteum.

\section{4. - LH-RH as an aid in medical insemination}

Irregularity of the cycles makes artificial insemination difficult, if not impossible, in women whose husbands are sterile.

In ro such cases we tried to evoke ovulation through $250 \mathrm{mcg}$ of $\mathrm{LH}-\mathrm{RH}$ injected twice at a twelve-hour interval. Although, the cervival mucus seemed to point out that we were near or at the appropriate moment, we were unable to obtain ovulation at the expected day. The same therapy, with the same negative results has been used by Gigon (I974), Nakano (I974), GRIMES and TaYmor (I974). 


\section{DISCUSSION}

Failures outnumber successes in all types of LH-RH treatment of an ovulatory sterility.

I. Considering the very short life of LH-RH, the failure of any treatment using L.H-RH alone in order to promote follicular growth could have been predicted. It would be very difficult, indeed, to simulate, the physiological action of FSH and LH : the pulsatory secretion of $\mathrm{LH}$, with its brief period would require a small pump injecting L,H-RH according to its physiological rhythm.

Also we do not even know whether L.H-RH is the only releasing factor, or whether there is a FSH-RH to regulate differently FSH and $\mathrm{LH}$ rate along the cycle.

One is rather tempted to wonder why such unphysiological schedules of therapy have been imagined and tried, and mostly how they can, have been successful. The versatility of the spontaneous evolution of amenorrhea could explain a certain number of successes. It could also be the case for luteal insufficiency.

2. The sequential therapy : clomifene citrate-LH-RH is less illogical. However there is an alternative : either the clomifene citrate fails to develop the follicular growth (then LH-RH cannot evoke ovulation), or the clomifene is active : it promotes the follicular ripening, with the secretion of estrogens and induces ovulation by itself. LH-RH would be only an adjunct, as is the more potent HCG, which is widely used.

\section{TABLEAU 6}

Some treatements of anovulatory women with $L H-R H$ alone or with other hormones

\begin{tabular}{|c|c|c|c|c|}
\hline \multirow{2}{*}{ Treatment } & \multirow{2}{*}{$\begin{array}{l}\text { Number } \\
\text { of cases }\end{array}$} & \multirow{2}{*}{$\begin{array}{c}\text { Ovulation } \\
\text { rates } \\
(\%)\end{array}$} & \multicolumn{2}{|c|}{ Pregnancies } \\
\hline & & & Number & $\%$ \\
\hline LH-RH alone & 87 & 27,5 & 7 & 8 \\
\hline $\mathrm{LH}-\mathrm{RH}+\mathrm{HCG}$ & 47 & 21 & 7 & 15 \\
\hline Clomid + LH-RH & 39 & 53,2 & 3 & 7,6 \\
\hline \multirow[t]{2}{*}{ HMG + LH-RH } & 46 & 25,5 & 3 & 6,5 \\
\hline & 219 & 33,3 & 20 & 9,2 \\
\hline
\end{tabular}

The use of LH-RH requires, however, a very good knowledge of the anatomical and hormonal events in every case, because its injections might interfere in the normal feed back between the ovaries, the hypothalamus and the hypophysis. This is not the case of HCG, which has very little FSH activity and acts only when the follicle is ripe. HCG has also the advantage of having a much longer life than LH-RH. 
The exact time when it should be injected is, from that standpoint, less important.

3. The sequence HMG-LH-RH seems to lie upon a better rationale. Once the follicle is ripe, it seems that it is the real physiological way to trigger ovulation.

The advantage upon $\mathrm{HCG}$ would be to prevent hyperstimulation. But this is rather theoretical. It postulates that the release of $\mathrm{LH}$ by the hypophysis cannot over pass the physiological limit. This is far from being proved. On the contrary, the release of LH and FSH depends upon the dose of LH-RH injected.

However, for the time being, no hyperstimulation syndrome has been observed. But the number of cases published in the literature is very poor ; no conclusion can be drawn concerning the danger of hyperstimulation. Unfortunately, there is a conclusion, at least provisional, about its efficiency, and this conclusion is very pessimistic: with the various techniques used so far, the results have been very poor (table 6).

\section{LH-RH IN THE MANAGEMEN'T OF MALE S'TERILITY}

The therapeutic trials with $\mathrm{LH}-\mathrm{RH}$ in male sterility have been very few.

The nasal route has been used by IsIDORI (r974), with a total daily dose of I ooo mcg divided into 5 snuffs.

The intramuscular route was employed by the other authors, at a daily dose of 100 to $500 \mathrm{mcg}$ injected once or twice a day, during 3 to 6 months.

SchWARSZTEIN (I974) reported 8 cases of oligospermia; 4 were moderate: 3 of them improved, even after the end of the treatment; one pregnancy occurred.

ZARATE's Io cases of male secretory sterility were more serious : although LH-RH seemed to alleviate the sperm deficiency in half of the cases, this improvement was very short. No pregnancy was observed.

So, the results, as could be expected, are most deceiving ; the successes obtained do not exclude chance.

It seems, however, that libido and sexual behaviour improved in the few cases in which they were altered.

Preliminary results of the treatment of hypogonadotropic hypogonadism have been published. It is too soon to estimate these fragmentary results (MoRTIMER et al., I974).

\section{CONCLUSION}

It seems that the main drawback of $\mathrm{LH}-\mathrm{RH}$ is its very brief life and very brief activity.

Research seems to be directed towards the discovery of long lasting LH-RH. A substance has been used by Amoss et al. (I974) in which D lysine is substituted to glycine in the molecule, and is tied to a sodium polyglutamate which is water soluble. The LH releasing activity of this peptide in the rat seems to last 6 times longer than the LH-RH itself. 
We ourselves have tried, with the same goal in mind, a molecule of LH-RH coupled with carboxymethylcellulose and another one with arginine-zinc both prepared by Rousser, chemical industries : without success.

NAKANo (I974) instead of loading the molecule, prepared a nonapeptide which ZARATE (I974) tried in Io cases. This molecule seems to be more active than LH-RH itself, and to last longer, since its activity was detected ro hours after its administration. ZARATE (I974) treated Io patients, restulting in 3 ovulations and 2 pregnancies.

In conclusion, the results of the management of secretory sterility in the human species are, for the moment rather deceiving.

However one must keep on mind that, in the beginnings, the treatment of anovulatory sterility through HMG was also most unsatisfactory, for instance with the first Stammers's method.

The present majority of failures could be related to somewhat anarchic schedules of treatment.

However, we feel that improvement should come from the discovery of a longer lasting LH-RH like substance, and also from a better understanding of the mechanism involved in the respective release of $\mathrm{FSH}$ and $\mathrm{LH}$, perhaps through the discovery of a FSH releasing factor.

Symposium Gn-RH, Tours, 25 mars 1975.

\author{
RÉSUMÉ \\ UTILISATION THEÉRAPEUTIQUE DU L,H-RH \\ DANS LES CAS D'INFERTILITÉ HUMAINE
}

Les auteurs ont tout d'abord rappelé quelques-unes des propriétés biologiques du LH-RH et l'efficacité des différentes voies d'administration.

Chez la Femme, la stérilité anovulatoire fonctionnelle semble être le cas d'élection d'une telle thérapeutique. Plusieurs modes de traitement ont été utilisés : LH-RH seul ou en association avec HMG, le clomifène ou HCG. Cependant, la proportion de succès (ovulation ou grossesse) est, pour le moment, décevante. Les auteurs pensent qu'une grande partie des échecs provient de schémas de traitement plutôt anarchiques.

Les essais thérapeutiques avec LH-RH pour traiter la stérilité masculine ont été peu nombreux chez l'Homme. Les quèlques succès qui ont pu être obtenus n'excluent pas le hasard.

L'amélioration des résultats dans l'utilisation thérapeutique du LH-RH doit venir d'une meilleure connaissance des mécanismes impliqués dans la décharge de FSH et de LH et de la découverte de LH-RH à durée de vie plus longue.

\title{
REFERENCES
}

Abate V., Maio T. J., I974. LH-RH used alone or in combination with HCG in treating anovulatory patients. 8th world Congr. Fertil. Steril., Buenos Aires, Abstr., 208.

Akande E. O., Carr P. J., Dutton A., 1972. Effect of synthetic gonadotropin releasing hormone in secondary amenorrhea. Lancet, 2, II2-I2I.

Amoss M. S., Monahan J. W., Verlander M. S., 1974. A long acting polymer coupled LRF anolog. J. Clin. Endocr. Metab., 39, I87-19I. 
Breck Woldt M., Czygan P. J., Lehmann F,, Bettendorf G., I974. Synthetic LH-RH as a therapeutic agent. Acta. Endocrin., 75, 209-220.

Bremmer W. J., Paulsen C. A., 1974. Two pools of luteinizing hormone in the human pituitary : evidence from constant administration of LH-RH. J. Clin. Endocrin., 39, 811-816.

Cortes J., Garcia D., Oriol-Bosch A., 1974. Induction of ovulation with combined LH-RH and human gonadotrophines administration. 8th IVorld Congress Fertil. Steril. Buenos Aires, Abstr. 202.

Crosignani P. G., Donini P., Trojsi L., Ragni G., I974. Induction of ovulation with synthetic LH-RH. 8th World Congr. Fertil. Steril., Buenos Aires, A bstr., 210.

GIgON U., I974. Triggering and timing of the ovulation by synthetic LH-RH. 8th World Congr. Fertil Steril., Buenos Aires, Abstr., 62.

Igarashi M., Yokota N., Ehara Y., Mayuzumi R., Hirano T., Matsumoto S., Yamasaki M., Ig68. Clinical effects with partially purified beef hypothalamic FSH releasing factor. Am. J. Obstet. Gynecol., 100, 867-870.

Isidori A., Fraioli F., Dondero F., 1974. Therapeutic evaluation of gonadotropin releasing hormone (LH-RH) in male hypogonadism. 8th world Congr. Fertil. Steril., Buenos Aires, Abstr., 506.

Kastin A. J., Zarate A., Migdley A. R., Canales E. S., Schally A. V., ig7r. Ovulation confitmed by pregnancy after infusion of porcine LH-RH. J. Clin. Endocr. Metab., 38, 980-982.

Kastin A. J., Schally A. V., Gonzalez Barcena D., Coy D. H., Miller M, C., Porias H., SCHALCH D. S., 1974. Clinical comparison of natural LH-RH, Synthetic LH-RH and two analogues of LH-RH. J. Clin. Endocr. Metab., 38, 801-804.

Kelch R. P., Clemens L. E., Markovs M., Westhoff M. M., Hawkins D. W., r975. Metabolism and effects of synthetic gonadotropin releasing hormone $(\mathrm{GnRH})$ in children and adults. J.Clin. Endocr. Metab., 40, 53-62.

KELLER P. J., I972. Induction of ovulation by synthetic luteinizing hormone releasing factor in infertile women. Lancet, 2, 570 .

KELLER P. J., I973. Treatment of anovulation with synthetic luteinizing hormone releasing hormone. Amr. J. Obstet. Gynecol., 116, 698-7ro.

Keye W. R., Kelch R. P., Niswender G. D., Jaffe R. B., I973. Quantitation of endogenous and exogenous gonadotropin releasing hormone by radioimmunoassay. J. Clin. Endocr. Metab., 36, 1263-1267.

Lehmann F., Bettendorf G., Breckwoldt M., Czygan P. J., i973. Therapeutic aspects of LHRH in ovarian insufficiency. Acta. Endocr. (Kbh), suppl. 173, go.

London D. R., BUTt W. R., IYNCH S. S., I973. Hormonal responses to intranasal LH-RH. J. Clin. Endocr. Metab., 37, 829-831.

Mortimer C. M., Besser G. M., Fischer R., 1974. Correction of hypogonadism by prolonged gonadotropin releasing hormone (LH/FSH-RH) therapy in patients with hypothalamic pituitary gonadal dysfunction. Endocrine Soc., Abstr. n० 8, Atlanta.

Miyachi Y., Mecklenburg R. S., Hansen J. W., Lifsett M. B., I973. Metabolism of ${ }^{185}$ I-Luteinizing hormone releasing hormone. J. Clin. Endocr. Metab., 37, 63-67.

Monahan M., Rivier J., Burgus R., Amoss M., Blackwell R., Vale W., Guillemin R., I97I. Synthèse totale par phase solide d'un décapeptide qui stimule la secrétion des gonadotrophines hypophysaires LH et FSH. C. $R$, acad. Sci. (Paris), 273, Série D, 508-510.

Naftolin F., Harris G. W., Bobrow M., 197r. Effect of purified luteinizing hormone releasing factor on normal and hypogonadotrophic anosmic men. Nature, 232, 496-497.

Nakano R., Katayama K., Mizuno T., Tojo S., I974. Induction of ovulation with synthetic luteinizing hormone releasing hormone. Fertil. Steril., 25, 471-477.

Nakano R., Takekida H., Kotsuji F., MiYazaki Y., Tojo S., I974. Gonadotropin response to a new analogue of $\mathrm{LH}-\mathrm{RH}$ (des-gly- $\mathrm{NH}_{2}$, proethylamide), LRF in men. J. Clin. Endocr. Metab., 39, $802-805$.

Rannevik G., Jeppson S., Kullanders, Thorell J., r973. Effects of synthetic LRF on plasma levels of FSH, LH and TSH in amenorrheic women and comparison of LH and FSH response after intravenous, intramuscular and sublingual administration. Acta Endocr. (Kgh), suppl. 177, 293.

Römmler A., Baumgarten S., Hammerstein J., I973. Hormonal response to multiple stimulation with synthetic LH-RH in amenorrheic women. 'Acta Endocr. (Kbh), suppl. I73, 87.

Schally A. V., Kastin A. J., Arimura A., I97r. Hypothalamic follicle stimulating hormone (FSH) and luteinizing hormone (LH) regulating hormone = structure physiology and clinical studies. Fertil. Steril., 22, 703-72I.

Schally A. V., Kastin A. J., Arimura A., 1972. The hypothalamus and reproduction. Amer. J. Obstet. Gynecol., 114, 423-442.

Schneider H. P. G., 1974. Utilization for therapeutic purposes in the female 8 th World Congr. Fertil. Steril. Buenos Aires, Abstr. 25.

Schwarsztein L., Aparicio N., Turner D., de Turner E. A., Mancini R., Schally A. V., I974. Synthetic luteinizing hormone releasing hormone in the treatment of oligospermia. 8th World Congr. Fertil. Steril., Buenos Aires, Abstr., 234. 
TAYMOR M. L., 1974. The use of luteinizing hormone releasing hormone in gynecologic endocrinology. Fertil. Steril., 25, 992-1005.

Virkkunen P., Lybeck H., Partanen J., Ranta T., Leppäluoto J., Seppälä M., I974. Plasma disappearance of injected synthetic LRH in man as measured by bioassay and radioimmunoassay. J. Clin. Endocr. Metab., 39, 702-706.

Zanartu J., Dabancens A., Kastin A. J., Schally A. W., 1974. Effect of synthetic hypothalamic gonadotrophin releasing hormone (FSH/LH-RH) in anovulation sterility. Fertil. Steril., 25, I60-I70.

Zanartu J., Aguilera E., Rodriguez Bravo R., Croxatto H., Schally A. V., r974. Ovulation induction = comparative study of the clinical efficacy of conventional LH-RH and new LH-RH analogues with higher LH and FSH releasing activity. Evoluation by direct observation of the gonadal response. 8th World Congr. Fertil. Steril., Buenos Aires, Abstr., 243.

Zarate A., Canales E. S., Schally A. V., I972. Successful induction of ovulation with synthetic luteinizing hormone releasing hormone in anovulatory infertility Fertil. Steril., 23, 672-674.

Zarate A., Valdis Vallina F., Gonzales A., Perez-Ubierna C., Canales E. S., Schally A. V. 1973. Therapeutic effect of synthetic luteinizing hormone releasing hormone (LH-RH) in male infertility due to idiopathic azoospermia and oligospermia. Fertil. Steril., 24, 485-486.

Zarate A., Canales E. S., Dela Cruz A., 1973. Pituitary response to synthetic LH-RH in Stein Leventhal syndrome and functional amenorrhea. Obstet. Gynecol., 41, 803-808.

Zarate A., Canales E.S., Soria J., Gonzales A., Schally A. V., Kastin A. J., i974. Further observations on the therapy of anovulatory infertility with synthetic luteinizing hormone releasing hormone. Fertil. Steril., 25, 3-10.

Zarate A., Canales E. S., Soria J., Schally A. V., Kastin A. J., Coy D., 1974. The use of LH-RH analogues with high LH-RH/FSHRH activity in induction of ovulation. 8th World Congr. Fertil. Steril., Buenos Aires, Abstr., 84. 